\title{
Nepovjerenje, spremnost i nelagoda roditelja djece $s$ teškoćama u razvoju prilikom traženja socijalno-stručne pomoći
}

\begin{abstract}
SAŽETAK
Temeljni cilj rada bio je ispitati koliko su roditelji djece s teškoćama u razvoju spremni potražiti socijalno-stručnu pomoć. Prvi specifični cilj bio je utvrditi na koji su način uvjerenja (nepovjerenje, spremnost i nelagoda u traženju socijalno-stručne pomoći) roditelja djece $s$ teškoćama u razvoju o budućem traženju socijalno-stručne pomoći povezana s procijenjenom prethodnom učestalosti dobivene socijalno-stručne podrške i zadovoljstvom prethodno dobivene socijalno-stručne podrške. Drugi specifični cilj je analizirati navedene varijable u odnosu na neka sociodemografska obilježja roditelja i djece (mjesto stanovanja i dob djeteta). Ispitivana su uvjerenja o traženju stručne pomoći te procjena učestalosti i zadovoljstva dobivenom stručnom podrškom kod 102 roditelja djece s teškoćama u razvoju dobi do 15 godina korisnika osam udruga i/ili institucija u kojima su uključeni u odgojno-obrazovni i socijalizacijsko-rehabilitacijski tretman. $U$ trenutku ispitivanja živjeli su u seoskim i urbanim sredinama na području gradova i okolice gradova Rijeke i Vinkovaca. Ukupno su sudjelovale $73(71.6 \%)$ majke $($ Mdob $=40.14)$ i $29(28.4 \%)$ očeva $($ Mdob = 41.52).

Procijenjena učestalost dobivene socijalno-stručne pomoći i procijenjeno zadovoljstvo dobivenom socijalno-stručnom pomoći su negativno povezani s većim nepovjerenjem prema traženju socijalno-stručne pomoći. Što su djeca starija, to se kod roditelja uočava manje spremnosti za traženje socijalno-stručne pomoći i više nepovjerenja u traženju stručne pomoći. Usporedbom roditelja u Vinkovcima i Rijeci, kao i usporedbom roditelja koji žive u gradu i roditelja koji žive na selu, utvrđeno je da roditelji koji žive u Vinkovcima, kao i roditelji koji žive na selu, iskazuju značajno veću nelagodu u traženju socijalno-stručne
\end{abstract}

\footnotetext{
* Učiteljski fakultet, Sveučilište u Rijeci, Rijeka, Hrvatska.

** Laboratorij za prevencijska istraživanja (PrevLab), Odsjek za poremećaje u ponašanju, Edukacijskorehabilitacijski fakultet, Sveučilište u Zagrebu, Zagreb, Hrvatska.

***** Osnovna škola „Mladost“ Lekenik, Lekenik, Hrvatska.

Adresa za korespondenciju: Nataša Vlah, Učiteljski fakultet, Sveučilište u Rijeci, Sveučilišna avenija 6, 51000 Rijeka, Hrvatska. E-pošta: natasa.vlah@uniri.hr.
} 
pomoći. Autorice se nadaju da rezultati mogu pomoći u budućim istraživanjima teme, kao i u unapređivanju sustavnog pružanja stručne pomoći i podrške obiteljima djece s teškoćama u razvoju. Smatraju da je rad važan u unaprjeđivanju kvalitete socijalno-stručne podrške i pomoći obiteljima djece $s$ teškoćama u razvoju jer ukazuje na teorijski interpretirano nisku roditeljsku procjenu učestalosti i kvalitete dobivene stručne pomoći.

Ključne riječi: djeca s teškoćama u razvoju, podrška roditeljima, selo, stručna pomoć, regionalne razlike

\section{UVOD}

Roditeljima djece s teškoćama u razvoju ${ }^{1}$ je radi svakodnevnih i razvojnih izazova koje nosi djetetova teškoća neophodna stručna pomoć i podrška² profesionalaca. Autorice ovog rada pri tome misle na sve profesionalne djelatnike u različitim sektorima koji mogu roditelje osnaživati u uspješnom odgoju djeteta i prevladavanju stresora koje imaju u vezi $s$ time. $S$ bioetičkog diskursa zaštite individualnih prava djece, prava za koja Pelčić i Gjuran Coha (2010) ističu da su univerzalno i sveobuhvatno opisana u Konvenciji o pravima djeteta (1989), proizlazi da je vrsta i trajanje stručne pomoći koja je djetetu potrebna u uskoj vezi s institutom informiranog pristanka djeteta i njegove obitelji na uključivanje u postupke prevencije, dijagnostike i tretmana. Različita su mišljenja autora o dinamici uloge obitelji i djeteta u davanju informiranog pristanka za uključivanje u preventivne i/ili dijagnostičke i/ili tretmanske postupke (Morrison i Feudtner, 2009; Pelčić i Gjuran Coha, 2010; Lyons, 2011; Kranželić, Kovčo Vukadin, Ferić, 2016) ali je u suvremenoj vrijednosnoj paradigmi stručnjaka bilo kojeg profila prihvaćeno da je kvalitetna komunikacija i suradnja stručnjaka s obitelji važna karika za dobrobit djeteta s teškoćama u razvoju (Murphy, 2018). U ovom radu se pod terminima socijalno-stručna podrška i socijalno-stručna pomoć smatra podrška i pomoć stručnjaka socijalnog, psihologijskog, edukacijsko-rehabilitacijskog i odgojno obrazovnog profila koji su educirani i usmjereni na pružanje pomoći u socijalizaciji, rehabilitaciji te odgoju i obrazovanju. U Hrvatskoj se socijalno-stručna pomoć profesionalnih stručnih djelatnika, poput socijalnih radnika, stručnjaka edukacijskorehabilitacijskog profila, psihologa, pedagoga, ali i odgajatelja i učitelja, može pružiti u različitim ustanovama socijalne skrbi, u školama, vrtićima ili civilnim udrugama. Istraživanja o povezanosti percepcije roditelja o učestalosti i zadovoljstva socijalno-

1 Prema Zakonu o socijalnoj skrbi, čl. 2 „Dijete s teškoćama u razvoju je dijete koje zbog tjelesnih, senzoričkih, komunikacijskih ili intelektualnih teškoća treba dodatnu potporu za učenje i razvoj kako bi ostvarilo najbolji mogući razvojni ishod i socijalnu uključenost." https://narodne-novine.nn.hr/clanci/sluzbeni/2012_03_33_798. html

2 Stručna pomoć i podrška je za djecu s teškoćama u razvoju multidisciplinarne prirode; prvenstveno se radi o medicinskoj stručnoj pomoći koja koegzistira sa spektrom podrške i pomoći iz oblasti socijalne skrbi, odgoja i obrazovanja, svakodnevne kvalitete života djeteta i obitelji i drugo. Radom se naglasak stavlja na one oblike stručne pomoći i podrške djetetu i obitelji koji slijede nakon i/ili paralelno $s$ medicinskom pomoći djetetu. 
stručnom podrškom koju dobiva i njegove spremnosti da aktivno potraži socijalnostručnu pomoć kada osjeti da mu je potrebna kako bi lakše prevladao stresore koje nosi odgoj djeteta s razvojnim teškoćama nema dovoljno. Zato postavljamo temeljno istraživačko pitanje rada u kojemu želimo ispitati kakva su uvjerenja roditelja djece s teškoćama u razvoju o traženju socijalno-stručne pomoći i kako su povezana s njihovom percepcijom prethodno dobivene socijalno-stručne podrške u centrima za socijalnu skrb, školama i vrtićima. Osobito je zanimljivo ispitati navedene koncepte dodatno u kontekstu demografskih varijabli djeteta i mjesta življenja obitelji. Pri tome će se među postojećim uvjerenjima o traženju socijalno-stručne pomoći na empirijskoj razini ispitivati tri vrste uvjerenja roditelja djece $s$ teškoćama u razvoju: nepovjerenje prema stručnjacima, spremnost za traženje stručne pomoći i nelagoda u traženju stručne pomoći.

Obitelj, još uvijek, predstavlja temeljnu jedinicu društva i primarno okruženje djetetova fizičkog, kognitivnog i socijalno emocionalnog razvoja te socijalizacije. Istraživanja jednoznačno pokazuju kako način roditeljstva ima značajan utjecaj na razvoj djeteta (Collins i sur., 2000). Kako se sve više gubi tradicionalna uloga zajednice i institucija, pred roditelje se postavljaju sve veći zahtjevi u razvoju djece. U isto vrijeme puno se govori o „pozitivnom roditeljstvu” i „roditeljstvu u najboljem interesu djeteta” (Vijeće Europe, Preporuka (2006) 19 o politici podrške pozitivnom roditeljstvu), „poticajnom roditeljstvu” ili drugim inačicama, poput „odgovornog roditeljstva”, „kompetentnog roditeljstva”, „autoritativnog roditeljstva” i „dovoljno dobrog roditeljstva”, a s druge strane društvo nudi malo prilika za podršku roditeljima da se ojačaju u istom.

Kada se radi o roditeljima djece s teškoćama u razvoju situacija postaje još složenija. Uz uobičajena pitanja na koje roditelji traže odgovor putem, najčešće, neformalnih oblika podrške i pomoći - prijatelja, proširene obitelji, literature, roditelji djece $s$ teškoćama u razvoju trebaju i sveobuhvatnu stručnu podršku i pomoć (Pećnik i Starc, 2010; Fareo, 2015; Ferić, 2015). Uz izazov suočavanja s informacijom da se njihovo dijete ne razvija u skladu s ostalom djecom njegove dobi, roditelji se suočavaju i s brojnim obavezama vezanim uz razvojni status djeteta. Vrlo brzo se pred roditelje postavljaju zadaci obilaženja brojnih ustanova kako bi pronašli adekvatan tretman, vrtić i/ili školu. Roditeljima se otvaraju pitanja specifičnosti roditeljstva djeteta $s$ teškoćom u razvoju, zaštita i prava djeteta te pitanja njihove fizičke i emocionalne snage za podizanje (Denona i Batinić, 2002; Diminić-Lisica i Rončević-Gržeta, 2010; Fox i Swett, 2017). Pred obitelji s djecom s teškoćama u razvoju puno je dodatnih izazova (utjecaj na partnerske odnose, karijeru, obiteljski život općenito) stoga je, kako bi zadržala funkcionalnost, potrebna relativno brza prilagodba novonastaloj (i često neočekivanoj) situaciji (Wallander i Varni, 1998; Matijaš, Ivšac Pavliša i Ljubešić, 2014). I dok se neki roditelji uspiju vrlo brzo prilagoditi situaciji te u njoj dobro 
funkcioniraju, kod velikog broja roditelja dolazi i do različitih oboljenja (Denona i Batinić, 2002). Istraživanja pokazuju kako je stres roditelja djece s teškoćama u razvoju vrlo visok (Martinac Dorčić i Ljubešić, 2008; Milić Babić, 2012). Kralj (2011, prema Dobrotić i Pećnik, 2013) izvještava kako čak 40 \% majki predškolske djece s teškoćama u razvoju po rezultatima prelazi granicu klinički značajnog stresa. Izvori stresa, odnosno brige, najčešće su vezani uz fizičko stanje djeteta, brigu za budućnost te ograničenost slobode izbora, što dovodi do emocionalne iscrpljenosti, ljutnje i opće napetosti (Leutar i Štambuk, 2007).

Roditeljima djece $s$ teškoćama u razvoju, zbog svega ranije navedenog, potrebni su i neformalni i formalni oblici podrške (Roehlkepartain i sur., 2002; Breitkreuz i sur., 2014). I dok se neformalni oblici podrške vežu uz „osobne resurse“ poput prijatelja, obitelji i široko dostupnih informacija (mediji, literatura, internet), formalni oblici vežu se uz stručnjake i javne politike/zakone u društvu koji bi trebali učinkovito i pravovremeno odgovoriti na potrebe roditelja (Redmond, Spoth i Trudeau, 2002; Attree, 2005). Stručna podrška je važna jer daje roditeljima mogućnost osnaživanja u ciljanim područjima života, odnosno prioritetnim potrebama, kao i oslonac za razvoj i održavanje osobnih kapaciteta u prevladavanju stresova koje neminovno imaju u svakodnevnoj brizi, skrbi i odgoju svog djeteta koje pored uobičajenih razvojnih zadaća ima i posebne potrebe (Wallander i Varni, 1998). Stručna podrška, ako je kvalitetna i relevantna, povećava otpornost cijele obitelji za prevladavanje izazova koje nosi razvojna teškoće njihova člana (Schembri Lia i Abela, 2016). Prema Pečnik (2013:18), u Hrvatskoj „prioritetne potrebe roditelja djece s razvojnim teškoćama prvenstveno su fokusirane na probleme u pravodobnom zadovoljavanju razvojnih potreba djece, na ograničene kapacitete postojećih usluga, na manjak stručnjaka i informacija, kompliciranu papirologiju, etiketiranje i diskriminaciju djece $s$ teškoćama te na odsutnost rane intervencije. Glavna je potreba za većom transparentnosti i boljom koordiniranosti usluga koje dolaze iz sustava zdravstva, obrazovanja i socijalne skrbi." Osim toga, u davanju usluge rane intervencije su u iskazima roditelja djece s teškoćama u razvoju (prema Milić Babić, Franc i Leutar, 2013) neka područja istaknuta kao važna za uspješnost rane intervencije: interdisciplinarni pristup, kompetentnost i motiviranost stručnjaka te suradni odnos s obitelji. Roditelji kao teškoće u sustavu vide: izostanak pravovremene podrške i informiranja, neprofesionalnost i organizacijske teškoće. Socijalni rad u ranoj intervenciji roditelji opisuju kroz iskustava obilježena roditeljskim nezadovoljstvom dobivenim informacijama, odnosom sa stručnjacima i organizacijom rada. Ipak roditelji vide važnost uključenosti socijalnog rada u sustav rane intervencije te ulogu socijalnog radnika opisuju kroz ulogu koordinatora sustava rane podrške, informatora i savjetovatelja (Milić Babić i sur., 2013). Osim navedenog, postoji utvrđena potreba roditelja za dodatnim sadržajima usmjerenim na pružanje usluga 
namijenjenih specifično djeci s teškoćama u razvoju koje se mogu opisati kroz: usluge organiziranog stručnog i odgojno obrazovnog čuvanja djeteta na kraće vremensko razdoblje i organiziranu stručnu podršku u domu djeteta (Batista, Jug i Milić Babić, 2014).

Proces traženja podrške vodi najčešće roditelja od neformalne podrške prema stručnoj podršci kada se ostali oblici pomoći pokažu nedovoljnima (Pećnik i Pribela-Hodap, 2013). Zbog navedenog, učestalost korištenja različitih oblika neformalne podrške zastupljenija je od formalnih oblika. Navedeno potkrepljuju i rezultati istraživanja provedenog u Hrvatskoj sa svrhom istraživanja potreba za podrškom u roditeljstvu koji pokazuju kako se roditelji djece od rođenja do polaska u školu za savjet u najvećem broju slučajeva obraćaju partneru/partnerici (87 \%), bliskim prijateljima koji imaju djecu (55\%), vlastitim roditeljima (54\%), zatim liječniku (38\%) i drugim članovima obitelji (27\%) te naposljetku, pred kraj ljestvice, stručnjacima različitih profila - odgojiteljicama u vrtiću (15\%), psihologu (7\%), pedagogu $(6 \%)$, dok logopedu, defektologu i zdravstvenoj voditeljici u svega $2 \%$ slučajeva (Pećnik i Pribela-Hodap, 2013). Slično, Girio-Herrera, Owens i Langberg (2013) navode kako roditelji najčešće traže pomoć liječnika i stručnih suradnika u odgojnim i/ili odgojno obrazovnim institucijama.

Traženje formalne, odnosno stručne podrške, obilježeno je percepcijom roditelja da neformalna podrška nije dovoljna kako bi se roditelji/obitelj nosili s izazovima pred njima. Prema rezultatima istraživanja Akister i Johnsona (2004) roditelji od stručnjaka najčešće traže: podršku (71\%), savjet (57\%), djelovanje (21\%) te informacije (21 $\%$ ). Rezultati istraživanja (Ghate i Hazel, 2004) pokazuju kako s formalnim oblicima podrške nije bilo upoznato $6 \%$ roditelja, dok $19 \%$ roditelja nije koristilo podršku stručnjaka ni u jednom trenutku. Ipak, isto istraživanje pokazuje kako je više od polovice ispitanika ( $54 \%$ ) bilo u kontaktu sa stručnjacima u posljednje 3 godine.

Roditelji od stručnjaka očekuju empatičnost, razumijevanje, suradnju, komunikativnost te spremnost da odgovore na sva pitanja koja ih zanimaju (Strauss i sur., 1995, prema Blaži i Kolarić, 2015). U istraživanju podrške roditeljstvu u kontekstu siromaštva roditelji su posebno cijenili stručne usluge koje su nudile praktičnu pomoć roditeljstvu, poput posjećivanja u vlastitom domu, preferirajući profesionalce koji nisu osuđujući, koji njihove brige shvaćaju ozbiljno i tretiraju ih s poštovanjem (Attree, 2005).

$S$ druge strane, neka istraživanja pokazuju kako roditelji izražavaju nezadovoljstvo lošom dostupnosti informacija, stoga nerijetko nailaze na poteškoće pronalaženja relevantnih i korisnih informacija (Košiček i sur., 2009; Ivšac Pavliša, 2010). Prema Košiček i sur. (2009) utvrdila se visoka razina nezadovoljstva roditelja pruženim informacijama o mogućnosti rehabilitacije te nezadovoljstvo suradnjom 
i komunikacijom među stručnjacima. Naime, $54 \%$ ispitanih nakon postavljene dijagnoze nisu dobili informacije o mogućnostima rehabilitacije nego su se morali informirati sami preko knjiga i interneta. Ivšac Pavliša (2010) među razloge otežanog dolaženja do informacija navodi sljedeće: „nepostojanje sustava rane intervencije, premalo stručnjaka specijaliziranih za rani razvoj, nedovoljna obaviještenost medicinskih struka o razvojnim fenomenima, nedostatak cjeloživotnog obrazovanja stručnjaka, centraliziranost savjetodavnih i terapijskih usluga u glavnim gradovima“" (Ivšac Pavliša, 2010: 280). Situaciju dodatno pogoršava (pre)velik vremenski razmak između trenutka kad se pojavi roditeljska zabrinutost i trenutka kada se obraćaju stručnjaku, pod objašnjenjem „Proći će“, „Pričekajte do pete godine“, „Neka djeca kasno progovaraju“ i slično (ibid.).

Istraživanja (Pećnik i Pribela-Hodap, 2013; Godoy i sur., 2014; Oh i Bayer, 2015) pokazuju kako su roditelji koji imaju pozitivno mišljenje o socijalno-stručnoj podršci i samom procesu savjetovanja skloniji potražiti socijalno-stručnu podršku. Pećnik i Pribela-Hodap (2013) navode kako čak 85 \% roditelja traženje stručne podrške kada je potrebna smatra znakom roditeljske odgovornosti, dok njih $78 \%$ smatra da bi im stručnjaci mogli pomoći. Nadalje, većina roditelja koja je koristila pomoć stručnjaka u socijalnoj ili odgojno-obrazovnoj skrbi ima pozitivna iskustva u vezi s njom, te bi je preporučila roditeljima u sličnim situacijama (88 \%). Slično potvrđuju Godoy i suradnici (2014) navodeći kako je traženje socijalno-stručne podrške pozitivno povezano s uvjerenjima o socijalno-stručnoj podršci, a uvjerenja o socijalno-stručnoj podršci su pozitivno povezana njenim primanjem. Oh i Bayer (2015) navode kako roditelji koji imaju pozitivnije namjere u traženju podrške podršku češće i ostvare, za razliku od roditelja koji su ambivalentni u svojoj namjeri. Iste autorice navode kako su rezultati istraživanja pokazali da je roditeljsko traženje podrške bilo slično, bez obzira na spol ili dob djeteta.

Iz navedenog je vidljivo kako uvjerenja roditelja o traženju socijalno-stručne pomoći utječu na samo traženje (i, posljedično, dobivanje) stručne pomoći, kao i da iskustvo dobivene socijalno-stručne podrške utječe na uvjerenja o stručnoj pomoći. Budući da u Hrvatskoj nema istraživanja koja se ciljano bave empirijskim utvrđivanjem navedenih relacija, namjera ovog rada je dati doprinos postojećim spoznajama o uvjerenjima roditelja vezanim uz traženje socijalno-stručne pomoći. Pri tome su u fokusu neke demografske (dob djeteta) ali i sociološke varijable poput teritorijalne pripadnosti istočnoj, manje razvijenoj ili zapadnoj, više razvijenoj regiji u Hrvatskoj (Radmanić i Funarić, 2014), što može biti relevantno za razvoj stavova i uvjerenja kod roditelja (Ilišin i Radin, 2002). Autorice rada smatrale su da je važno ispitati i relacije fokusnih varijabli s varijablama života u gradu ili na selu radi činjenice poznate u stručnim krugovima da se timovi stručne pomoći u Hrvatskoj centriraju u 
gradovima, što može biti relevantno za dostupnost stručne pomoći obiteljima djece $s$ teškoćama u razvoju na selu³.

\section{CILJ RADA I HIPOTEZE}

Temeljni cilj rada bio je ispitati koliko su roditelji djece s teškoćama u razvoju spremni potražiti socijalno-stručnu pomoć. U odnosu na temelji cilj, razrađena su dva specifična cilja rada. Prvi specifični cilj je utvrditi na koji su način uvjerenja (nepovjerenje, spremnost i nelagoda) roditelja djece s teškoćama u razvoju o budućem traženju socijalno-stručne pomoći povezana s procijenjenom prethodnom učestalosti dobivene socijalno-stručne podrške i zadovoljstvom prethodno dobivene socijalnostručne podrške. Drugi specifični cilj je analizirati navedene varijable u odnosu na neka sociodemografska obilježja roditelja i djece (mjesto stanovanja i dob djeteta). Slijedom toga, istraživački problemi ovog rada su utvrditi:

1. uvjerenja (nepovjerenje, spremnost i nelagodu) roditelja djece s teškoćama o traženju socijalno-stručne pomoći s obzirom na dob djeteta i mjesto stanovanja obitelji;

2. procjenu učestalosti dobivene socijalno-stručne podrške i procjenu zadovoljstva dobivenom socijalno-stručnom podrškom s obzirom na dob djeteta i mjesto stanovanja obitelji;

3. povezanost između učestalosti dobivene socijalno-stručne podrške te zadovoljstva dobivenom socijalno-stručnom podrškom i uvjerenja (nepovjerenje, spremnost i nelagoda) o traženju socijalno-stručne pomoći roditelja djece s teškoćama.

Uzimajući u obzir cilj istraživanja te istraživačke probleme, hipoteze istraživanja su sljedeće:

H1: Postoje značajne relacije u uvjerenjima (nepovjerenju, spremnosti i nelagodi) o traženju socijalno-stručne pomoći s obzirom na dob djeteta i mjesto stanovanja obitelji tako da roditelji djece niže dobi i oni koji žive u gradu, a ne u selu, te oni koji žive u Rijeci, a ne u Vinkovcima, imaju pozitivnija uvjerenja (nepovjerenje, spremnost i nelagoda) o traženju socijalno-stručne podrške.

H2: Postoje značajne relacije u procijenjenoj učestalosti dobivene socijalno-stručne podrške i procijenjenom zadovoljstvu dobivene socijalno-stručne podrške s obzirom na dob djeteta i mjesto stanovanja obitelji, tako da roditelji djece niže dobi i oni koji

3 U Hrvatskoj je rizik od siromaštva u ruralnim područjima gotovo tri puta veći nego u urbanim područjima (Nestić i Vecchi, 2014). 
žive u gradu (a ne na selu) te oni koji žive u Rijeci (a ne u Vinkovcima) procjenjuju veću učestalost i zadovoljniji su dobivenom socijalno-stručnom podrškom.

H3: Postoji značajna pozitivna povezanost između uvjerenja (nepovjerenje, spremnost i nelagoda) o traženju socijalno-stručne pomoći i učestalosti/zadovoljstva socijalnostručnom podrškom kod roditelja djece s teškoćama u razvoju.

\section{METODA}

\section{Uzorak sudionika}

Uzorak je neprobabilistički prigodni, namjerno formiran prema postavljenom prvom i drugom istraživačkom problemu kojim se žele utvrditi relacije između mjesta stanovanja i fokusnih varijabli. $U$ istraživanju su sudjelovala 102 roditelja djece $s$ teškoćama u razvoju koji žive na području gradova i okolice gradova Rijeke i Vinkovaca. Od ukupno 15 udruga i ustanova koje okupljaju roditelje djece s teškoćama koji su zamoljeni za sudjelovanje, u istraživanju se odazvalo 8 udruga i ustanova: Udruga osoba s invaliditetom Bubamara $11.76 \%$ (Vinkovci), Centar za rehabilitaciju Mala Terezija 15.69 \% (Vinkovci), Dječji vrtić 7.84 \% (Vinkovci), Dječji vrtić Rijeka 12.75 \%, Dnevni centar za rehabilitaciju Slava Raškaj 15.69 \% (Rijeka), Udruga osoba s cerebralnom i dječjom paralizom 12.75 \% (Rijeka), te osnovne škole „Fran Frankovič 9.84 \% i „Gornja Vežica“ 13.73 \% (Rijeka). Ukupno su sudjelovale $73(71.6 \%)$ majke (Mdob = 40.14 godina) i $29(28.4 \%)$ očeva (Mdob $=41.52$ godina). $\mathrm{U}$ ukupnom uzorku su bili roditelji $32(31.37 \%)$ djece $s$ više vrsta i stupnjeva teškoća, $25(24.51 \%)$ djece s poremećajem govornoglasovne komunikacije i specifičnim teškoćama u učenju, 21 (20.59 \%) dijete $s$ tjelesnim invaliditetom te $15(14.71 \%)$ djece s poremećajima iz autističnog spektra, $5(4.90 \%)$ djece s oštećenjem sluha, $2(1.96 \%)$ djece s intelektualnim teškoćama, $2(1.96 \%)$ djece s poremećajima u ponašanju uvjetovanima organskim faktorima ili psihozom. Među višestrukim teškoćama su kombinacije autizam i poremećaji govorno-glasovne komunikacije te specifične teškoće u učenju, odnosno tjelesni invaliditet $\mathrm{i}$ intelektualne teškoće te poremećaji u ponašanju uvjetovani organskim faktorima ili psihozom i autizam. Što se tiče uključenosti djeteta u neki oblik stručnog tretmana, dnevnog ili poludnevnog boravka stručne institucije, 93 (94.90 \%) roditelja izjasnila su se da dijete pohađa jedan od oblika stručne pomoći, dok je 5 roditelja $(5.10 \%)$ odgovorilo da dijete nije uključeno niti u jedan oblik socijalnostručne pomoći, što je samo po sebi iznenađujuće da roditelj smatra da mu dijete nije uključeno u oblik stručne pomoći, bez obzira što je korisnik usluge udruge, odnosno institucije koja zapošljava takve stručnjake. Roditelji koji su odgovorili da dijete ne pohađa niti jedan od oblika socijalno-stručne pomoći nalaze se u gotovo jednakom 
omjeru u oba ispitana grada. Sukladno ustanovama u kojima su ispitivani, roditelji su kao mjesta u kojima su djeca uključena u neke oblike socijalno-stručnih tretmana u najvećoj mjeri isticali upravo te udruge/ustanove. Ukupno 4 (3.9\%) roditelja nije odgovorilo na pitanje.

Vezano uz hipoteze istraživanja važno je istaknuti da je 71 (69.6 \%) sudionik istraživanja živio u gradu, dok je njih 31 (30.4\%) živjelo na selu u trenutku provođenja istraživanja. Radilo se o roditeljima 40 (39.22 \%) djevojčica $\left(\mathrm{M}_{\mathrm{dob}}=8.28\right.$; $\mathrm{Min}=3$; Maks = 15 godina $)$ i $62(60,78 \%)$ dječaka $\left(M_{\text {dob }}=6.76\right.$ godina; Min = 3; Maks =14 godina) s teškoćama u razvoju. U Rijeci je anketirano 66 (64.7\%) roditelja, dok je u Vinkovcima anketirano $36(35.3 \%)$ roditelja.

\section{Mjerni instrumenti}

Podaci su prikupljeni Upitnikom za roditelje u kojemu su integralno, osim općih demografskih podataka, mjerena uvjerenja roditelja djece s teškoćama u traženju stručne pomoći (Pećnik, 2014.), kao i procjena roditelja o učestalosti dobivanja stručne podrške (Leutar i Oršulić, 2015.) te zadovoljstva dobivenom stručnom podrškom (Leutar i Oršulić, 2015.).

Tablica 1. Faktorska struktura Skala uvjerenja o traženju stručne pomoći - matrica obrasca

Faktori

(1) (2)

\begin{tabular}{lc}
\hline $\begin{array}{l}\text { 8. Stručnjaci poznaju teoriju, ali slabo mogu razumjeti stvarne } \\
\text { probleme roditelja }\end{array}$ & .80 \\
\hline \begin{tabular}{l} 
11. Teško mi je o problemima govoriti nepoznatoj osobi \\
\hline $\begin{array}{l}\text { 9. Ne vjerujem da roditelju u problemu može pomoći } \\
\text { stručnjak koji ne poznaje njegovo dijete }\end{array}$
\end{tabular} & .74 \\
\hline $\begin{array}{l}\text { 10. Kada se roditelj povjeri stručnjaku u vrtiću/predškoli, } \\
\text { dijete postaje obilježeno? }\end{array}$ & .68 \\
\hline $\begin{array}{l}\text { 7. Stručnjaci nameću roditeljima svoja shvaćanja o djetinjstvu } \\
\text { 13. Roditeljske brige koje govorim stručnjacima oni } \\
\text { zloupotrjebljavaju protiv mene }\end{array}$ & .67 \\
\hline $\begin{array}{l}\text { 4. Kada imam probleme u roditeljstvu, vjerujem da će mi } \\
\text { stručnjaci pomoći }\end{array}$ & .62 \\
\hline $\begin{array}{l}\text { 3. Kada mislim da kao roditelj gubim kontrolu, odmah } \\
\text { potražim stručnu pomoć }\end{array}$ & .76 \\
\hline \begin{tabular}{l} 
1. Traženje stručne pomoći znak je roditeljske odgovornosti \\
\hline
\end{tabular} & .73 \\
\hline
\end{tabular}


2. Rado osobne stvari povjeravam odgovarajućem stručnjaku kada mislim da to može pomoći meni ili mom djetetu

5. Kada sam odlučio potražiti stručnu pomoć u roditeljstvu, imao sam jasnu ideju o tome što napraviti te s kim razgovarati

6. Stručnjake trebaju problematične obitelji, a ja kao prosječan roditelj teškoće u roditeljstvu rješavam sam

.71

15. Bilo bi me sram kada bi me vidjeli kako ulazim u prostor stručne osobe koja se bavi obiteljskim problemima

14. Bilo mi je neugodno potražiti stručnu pomoć jer bi to ljudi u mojoj okolini mogli doznati

12. Brinem se da će stručnjak tražiti da promijenim svoje ponašanje

Postotak varijance

33.88

.44

Cronbachova Alpha $(\alpha)$

.82

.80 .76

Skala uvjerenja o traženju stručne pomoći preuzeta je i adaptirana iz UNICEF-ove publikacije Kako roditelji i zajednice brinu o djeci najmlade dobi u Hrvatskoj (Pećnik, 2014). Skalom se ispituju uvjerenja roditelja u odnosu na stručnu pomoć. $\mathrm{Na}$ rezultatima prikupljenim u istraživanju na setu od 15 čestica provedena je komponentna analiza prema Gutman-Keiserovu kriteriju te su ekstrahirane 3 komponente karakterističnih korijena viših od 1 (5.09, 2.3, 1.37.) koje su potom rotirane Oblimin kosokutnom rotacijom radi utvrđivanja konačne faktorske strukture ispitivanog seta čestica. Dobivena su tri faktora (konstrukta) kako je vidljivo u Tablici 1. To su: (1) nepovjerenje prema stručnjacima $(\mathrm{k}=6$; marker varijabla Stručnjaci poznaju teoriju, ali slabo mogu razumjeti stvarne probleme roditelja), (2) spremnost za traženje stručne pomoći $(\mathrm{k}=5$; marker varijabla Kada imam probleme u roditeljstvu, vjerujem da će mi stručnjaci pomoći) i (3) nelagoda u traženju stručne pomoći ( $\mathrm{k}=$ 4; marker varijabla Stručnjake trebaju problematične obitelji, a ja kao prosječan roditelj teškoće u roditeljstvu rješavam sam). Ispitanici su zaokruživali odgovore na ljestvici od pet stupnjeva: 1 = Uopée nije točno za mene; 2 = Uglavnom nije točno za mene; 3 = Niti je točno niti je netočno za mene; 4 = Uglavnom je točno za mene; 5 = Potpuno je točno za mene. U sva tri konstrukta koji su mjerili uvjerenja roditelja o traženju stručne pomoći niži rezultat znači niža, negativnija uvjerenja o pojedinom konstruktu, a viši rezultat upućuje na viša, pozitivnija uvjerenja prema istim konstruktima. Dakle, adaptacijom Skala uvjerenja o traženju stručne pomoći (Pećnik, 2014) dobivena je Skala uvjerenja roditelja djece s teškoćama u razvoju o traženju socijalno-stručne pomoći koja sa svoje tri subskale mjeri tri vrste uvjerenja. Prvo je nepovjerenje prema stručnjacima (dalje: nepovjerenje) kojim se izražava uvjerenje roditelja da stručnjaci 
samo teoretiziraju i ne pomažu konkretno, da su stručnjaci za roditelje nepoznate osobe, da će dijete biti stigmatizirano ako se obrate stručnjacima, da su stručnjaci agresivni i nedobronamjerni. Druga vrsta uvjerenja je spremnost za traženje stručne pomoći (dalje: spremnost) putem koje se mjeri vjerovanje da će stručnjaci pomoći i to osobito kada se roditelju učini da nema kontrolu u svom roditeljstvu djeteta s teškoćama u razvoju, uvid roditelja da je traženje pomoći znak odgovornosti, otvorenost za povjeravanje $s$ jasnim očekivanjem kako stručnjak može kvalitetno pridonijeti kvaliteti života. Treća vrsta uvjerenja je nelagoda u traženju stručne pomoći (dalje: nelagoda), a radi se o subskali koja mjeri roditeljevu predrasudu da stručnjake trebaju samo problematične obitelji, osjećaje straha, nelagode i srama da će traženje stručne pomoći izazvati osudu i podsmjeh bliže okoline, ali i strah od stručnjakova pritiska na eventualnu promjenu ponašanja.

$\mathrm{Za}$ mjerenje učestalosti dobivene stručne podrške i zadovoljstva dobivenom stručnom podrškom korišten je dio čestica Upitnika socijalne podrške, Social Support Inventory (SSI) Sarasona i suradnika (1983., prema Leutar i Oršulić, 2015.). Od 4 vrste podrške koje su koristile Leutar i Oršulić (2015) za ovo istraživanje odabrana je samo emocionalna/moralna podrška koju roditelji mogu dobivati, a unutar nje nas je ciljano zanimalo mišljenje roditelja isključivo vezano samo uz njihovu procjenu emocionalne/moralne podrške koju dobivaju od stručnjaka. Stoga je za potrebe ovog istraživanja korištena subskala učestalost podrške stručnjaka $(\mathrm{k}=3 ; \alpha=.68$, stručnjaci centra za socijalnu skrb; školelvrtića) pri čemu su ispitanici učestalost stručne podrške procjenjivali na peterostupanjskoj skali od nikad/izrazito rijetko do izrazito često. Korištena je i subskala zadovoljstvo podrškom stručnjaka $(\mathrm{k}=3 ; \alpha=.71$; stručnjaci centra za socijalnu skrb; stručnjaci škole/vrtića) na kojoj su svoje zadovoljstvo stručnom podrškom ispitanici iskazivali na skali od pet stupnjeva od u potpunosti sam nezadovoljan do u potpunosti sam zadovoljan.

\section{Postupak prikupljanja podataka}

Istraživanje je provedeno tijekom travnja i svibnja 2016. godine. Etički kodeks istraživanja s djecom (2003) uvažavan je tako da su roditeljima, bilo usmenim, bilo pismenim putem priopćeni: svrha istraživanja, opće i posebne koristi istraživanja, nepostojanje rizika od sudjelovanja, vrsti i trajanju postupka, povjerljivosti dobivenih podataka, zaštiti privatnosti sudionika, nepostojanju negativnih posljedica koje istraživanje može izazvati, dragovoljnosti sudjelovanja i pravu na odustanak od sudjelovanja u anonimnom i dobrovoljnom istraživanju. Svaki od roditelja koji je ispunio podatke dao je svoj informirani pristanak na sudjelovanje u istraživanju. Jedna od autorica rada je na terenu u navedenim udrugama i institucijama prikupljala podatke za širi projekt svog diplomskog rada (Raguž, 2016). Upitnici nisu ispunjavani na licu mjesta nego su uručivani roditeljima, koji su ih nakon 
ispunjavanja u zatvorenoj omotnici vraćali koordinatorima u pojedinoj instituciji/ udruzi. Ukupno je podijeljeno 160 upitnika, od čega je 110 vraćeno ispunjeno, od čega 102 valjano. Prosječno vrijeme ispunjavanja bilo je oko 15 minuta.

\section{Obrada podataka}

Faktorska je analiza korištena radi utvrđivanja konstruktne valjanosti skala za mjerenje uvjerenja za traženje stručne pomoći (prikazano u mjerni instrumenti), kao i procjene učestalosti dobivenom stručnom podrškom i zadovoljstva dobivenom stručnom podrškom. Svaki faktor/dimenzija, odnosno subskala/koncept je dalje promatran kao prosječna vrijednost subskale/koncepta u daljnjim analizama. Utvrđene su osnovne deskriptivne mjere (minimalne i maksimalne vrijednosti za svaku subskalu/koncept aritmetičke sredine i standardne devijacije). S obzirom na to da Kolmogorov-Smirnovljev test ukazuje na odstupanja normalnosti distribucije u svim dimenzijama, korištene su neparametrijske statističke metode: Spearmanova korelacija te Mann-Whitneyjev test.

\section{REZULTATI}

U odnosu na prvo i drugo istraživačko pitanje, istražiti uvjerenja (nepovjerenje, spremnost i nelagoda) roditelja djece $s$ teškoćama o traženju socijalno-stručne podrške, odnosno procjenu učestalosti dobivene socijalno-stručne podrške i procjenu zadovoljstva dobivenom socijalno-stručnom podrškom $s$ obzirom na dob djeteta i mjesto stanovanja obitelji, rezultati pokazuju (Tablica 2.) kako nema značajnih razlika u procijenjenoj učestalosti socijalno-stručne podrške i procijenjenom zadovoljstvu socijalno-stručnom podrškom s obzirom na mjesto i grad stanovanja, niti povezanosti ovih varijabli s dobi djeteta (Tablica 3). Premda se u nepovjerenju prema stručnjacima i spremnosti za traženje stručne pomoći roditelji u Vinkovcima i Rijeci, odnosno na selu i gradu, ne razlikuju, postoji značajna razlika u ta dva demografska prostora analize $s$ obzirom na nelagodu u traženju stručne pomoći. Naime roditelji djece $s$ teškoćama u razvoju koji žive u Vinkovcima (kada se uspoređuje Rijeka i okolica s Vinkovcima i okolicom), roditelji djece koji žive na selu (kada se uspoređuje selo i grad kao takvi, bez obzira radi li se o području Rijeke ili Vinkovaca) imaju značajno veći rezultat na dimenziji „nelagoda u traženju stručne pomoći“. Radi potpunijeg razumijevanja rezultata, razmjerno više ispitanika iz područja Rijeke živi u gradu, dok ih s područja Vinkovaca podjednako živi i u gradu i na selu $\left(\chi^{2}=5.13^{*}\right.$; $\left.\mathrm{df}=1\right)$. 
Tablica 2. Razlike među skupinama na dimenzijama učestalosti i zadovoljstva socijalno-stručnom podrškom te uvjerenja o traženju socijalno-stručne pomoći (nepovjerenje, povjerenje, nelagoda) u odnosu na mjesto stanovanja obitelji

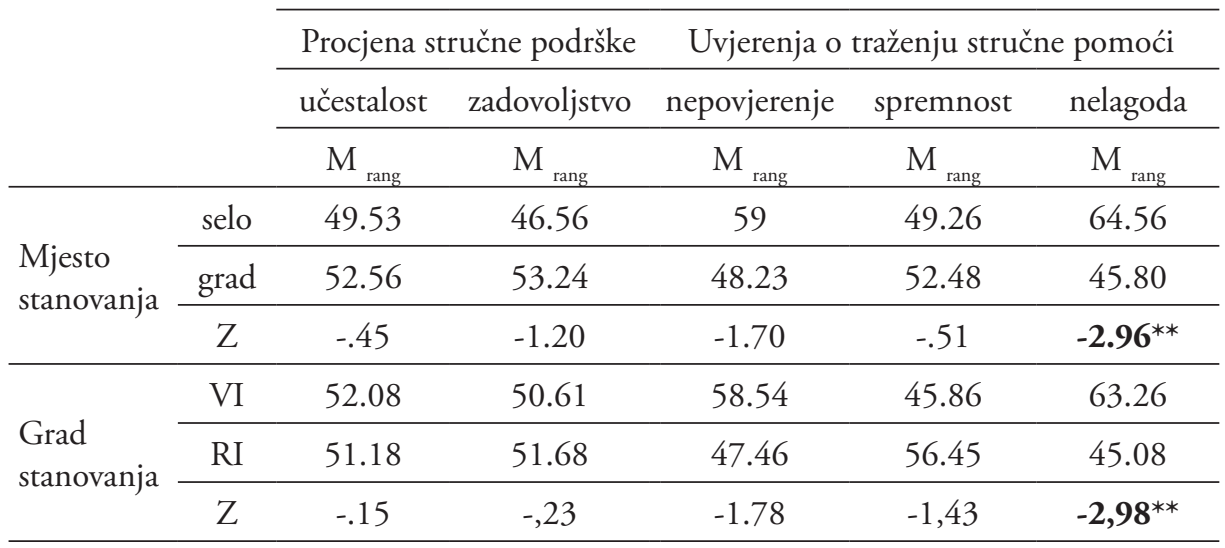

Kazalo: $\left(\mathrm{N}_{\text {selo }}=31 ; \mathrm{N}_{\text {grad }}=71\right)$ i grad stanovanja obitelji $\left(\mathrm{N}_{\text {Rijeka }}=66 ; \mathrm{N}_{\text {Vinkovci }}=36\right), \mathrm{Z}=$ vrijednost Mann-Whitneyjeva $\mathrm{U}$ testa; ${ }^{*}=p<0.05 ;{ }^{* *}=p<0.01 ;{ }^{* * *}=p<0.001 ; \mathrm{M}$ rang = prosječna vrijednost

Treće istraživačko pitanje odnosilo se na povezanost između učestalosti dobivene socijalno-stručne podrške te zadovoljstva dobivenom socijalno-stručnom podrškom i uvjerenja u traženju socijalno-stručne pomoći roditelja djece s teškoćama. Prije odgovaranja na njega, pogledajmo deskriptivne pokazatelje triju vrsta uvjerenja (nepovjerenje, spremnost i nelagoda) s obzirom na temeljne deskriptivne pokazatelje (Tablica 3.). Roditelji djece $s$ teškoćama u razvoju učestalost dobivene podrške stručnjaka procjenjuju između rijetko $i$ ponekad, dok zadovoljstvo dobivenom podrškom stručnjaka procjenjuju s niti sam zadovoljan niti sam nezadovoljan. Njihova uvjerenja (nepovjerenje, spremnost i nelagoda) o traženju pomoći stručnjaka su, kao i kod procjene dobivene podrške stručnjaka u rasponu od minimalne do maksimalne. Spremnost za traženje socijalno-stručne pomoći kod roditelja blago pozitivno izražena (uglavnom su spremni potražiti pomoć, ali ne potpuno). Roditelji su osrednje nepovjerljivi prema traženju pomoći stručnjaka (birali su uglavnom odgovore niti je točno niti je netočno za mene). I na kraju, dimenzija nelagode roditelja u traženju stručne pomoći iskazana je neodlučnošću. Dakle, prema prosječnim vrijednostima je vidljivo (Tablica 3.) kako su roditelji iz ovog prigodnog uzorka skoro pa gotovo uvijek spremni za traženje stručne pomoći, da su osrednje nepovjerljivi prema stručnjacima, te uglavnom neodlučni glede nelagode u traženju stručne pomoći. 
Tablica 3. Deskriptivni parametri i Spearmanove mjere povezanosti između percipirane učestalosti i podrške stručnjaka te uvjerenja o traženju pomoći stručnjaka

\begin{tabular}{|c|c|c|c|c|c|c|c|c|c|c|}
\hline & & $\stackrel{\Xi}{\Sigma}$ & $\frac{\frac{y}{\pi}}{\sum}$ & $\Sigma$ & a & 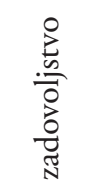 & 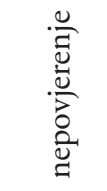 & 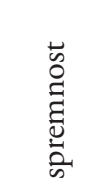 & $\begin{array}{l}\frac{\pi}{0} \\
\frac{8}{\pi} \\
\frac{\pi}{\mathscr{U}}\end{array}$ & 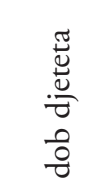 \\
\hline \multirow{2}{*}{$\begin{array}{l}\text { podrška } \\
\text { stručnjaka }\end{array}$} & učestalost & 1 & 5 & 2.72 & .94 & $.79^{* *}$ & $-.26^{* *}$ & -.05 & -.00 & -.01 \\
\hline & zadovoljstvo & 1 & 5 & 3.25 & 1.08 & & $-.20 *$ & -.05 & -.00 & -.07 \\
\hline \multirow{3}{*}{$\begin{array}{l}\text { traženje } \\
\text { pomoći } \\
\text { stručnjaka }\end{array}$} & nepovjerenje & 1 & 5 & 2.70 & .87 & & & $-.34^{* *}$ & $.51^{* *}$ & $.20^{*}$ \\
\hline & spremnost & 1 & 5 & 3.70 & .75 & & & & $-.37^{* *}$ & $-.25^{* *}$ \\
\hline & nelagoda & 1 & 5 & 2.24 & .85 & & & & & .11 \\
\hline
\end{tabular}

Kazalo: Minimalne i Maksimalne vrijednosti, aritmetičke sredine (M), Standardne devijacije (SD), Spearmanovi koeficijenti korelacije za dimenzije učestalosti podrške stručnjaka, zadovoljstva podrškom stručnjaka, uvjerenja u traženju socijalno-stručne pomoći (nepovjerenje, spremnost, nelagoda), ${ }^{* *} p<0,01,{ }^{*} p<0,05$

Interkorelacija između dimenzija procijenjene učestalosti dobivenom socijalnostručnom podrškom i zadovoljstva dobivenom socijalno-stručnom podrškom (Tablica 3.) je pozitivna i visoka. Međusobne povezanosti između dimenzija uvjerenja traženja socijalno-stručne pomoći međusobno su nisko do srednje povezane, pri čemu je evidentno da roditelji koji osjećaju veću nelagodu prema traženju socijalnostručne pomoći stručnjaka prema stručnjacima iskazuju i veće nepovjerenje u traženju iste. Spremnost za traženje socijalno-stručne pomoći je i s nepovjerenjem prema stručnjacima i s nelagodom prema stručnjacima negativno nisko povezana što je logično, jer ako je veća spremnost za traženje stručne pomoći, bit će manje nepovjerenje/nelagoda i obrnuto. Roditelji koji pokazuju veću spremnost za traženje socijalno-stručne pomoći osjećaju manju nelagodu prema stručnjacima i obrnuto, što je veći osjećaj nelagode prema stručnjacima manji je osjećaj spremnosti za traženje socijalno-stručne pomoći kod roditelja djece s teškoćama u razvoju.

Prisutna je negativna i niska povezanost između procijenjene učestalosti dobivene podrške stručnjaka i nepovjerenja prema traženju pomoći od stručnjaka. Roditelji koji procjenjuju da češće primaju podršku stručnjaka ne osjećaju nepovjerenje prema traženju njihove pomoći. Slično tome, postoji negativna i niska povezanost između procijenjenog zadovoljstva podrškom stručnjaka i nepovjerenja prema traženju pomoći od stručnjaka, što ukazuje da roditelji koji su zadovoljniji podrškom stručnjaka manje osjećaju nepovjerenje prema traženju njihove pomoći. 
Dob djeteta negativno je povezana sa spremnošću roditelja za traženje socijalnostručne pomoći, odnosno roditelji mlađe djece iskazuju više spremnosti prema traženju socijalno-stručne pomoći od roditelja starije djece. Tome se nadovezuje rezultat pozitivne povezanosti nepovjerenja prema stručnjacima i dobi, što ukazuje da, što su djeca starija, roditelji osjećaju više nepovjerenja prema stručnjacima.

\section{RASPRAVA REZULTATA I ZAKLJUČAK}

Temeljni cilj rada bio je ispitati koliko su roditelji djece s teškoćama u razvoju spremni potražiti socijalno-stručnu pomoć. Prvi specifični cilj rada bio je utvrditi na koji su način nepovjerenje, spremnost i nelagoda roditelja djece s teškoćama u razvoju o budućem traženju socijalno-stručne pomoći povezana s procijenjenom prethodnom učestalosti dobivene socijalno-stručne podrške i zadovoljstvom prethodno dobivene socijalno-stručne podrške. Drugi specifični cilj je bio analizirati navedene varijable u odnosu na mjesto stanovanja i dob djeteta. Da bi se ostvarili navedeni ciljevi, u ovom je radu adaptacijom Skale uvjerenja o traženju stručne pomoći (Pećnik, 2014), prethodno derivirana Skala uvjerenja roditelja djece s teškoćama u razvoju o traženju socijalno-stručne pomoći koja sa svoje tri subskale mjeri tri vrste uvjerenja roditelja djece s teškoćama u razvoju: nepovjerenje prema stručnjacima, spremnost za traženje stručne pomoći i nelagoda u traženju stručne pomoći.

Prema osnovnim rezultatima, roditelji djece s teškoćama u razvoju učestalost dobivene socijalno-stručne podrške, kao i zadovoljstvo tom podrškom procjenjuju osrednjom, dok su njihova uvjerenja o traženju socijalno-stručne pomoći neutralna. $S$ obzirom na teoriju o navedenoj vrsti stručne pomoći roditeljima djece s teškoćama $\mathrm{u}$ razvoju, rezultati dobiveni glede nepovjerenja i nelagode $\mathrm{u}$ traženju socijalnostručne pomoći su u ovom uzorku sudionika nepovoljni i zabrinjavajući. Rezultati su također pokazali da nema razlika u procijenjenoj učestalosti dobivene socijalnostručne pomoći i zadovoljstvu dobivenim socijalno-stručnom pomoći u odnosu na dob djeteta i mjesto stanovanja (grad/selo, Rijeka/Vinkovci). Ako se usmjerimo na uzorak, roditelje djece s teškoćama u razvoju koja svakako trebaju dodatnu socijalnostručnu pomoć, rezultati upućuju na zaključak da roditelji nisu u dovoljnoj mjeri spremni tražiti socijalno-stručnu pomoć. U relacijama sa činjenicom da procjenjuju dobivenu socijalno-stručnu podršku u srednjoj mjeri i da su osrednje zadovoljni istom, nije čudno da nisu u dovoljnoj mjeri spremni tražiti socijalno-stručnu pomoć. Naime, ako se netko navikne na činjenicu da mu pružena stručna pomoć nije visoko učestala, niti je visoko zadovoljan njome, neće vjerojatno biti osobito motiviran da samostalno aktivno i potraži socijalno-stručnu pomoć kada mu je potrebna. To bi se moglo nazvati učenje prema vlastitom iskustvu roditelja djece $s$ teškoćama u 
razvoju u interakciji sa stručnjacima u centrima za socijalnu skrb, školama i vrtićima iz ovog istraživanja. Dapače, ovu pretpostavku dopunjuje i rezultat prema kojemu je niže procijenjena učestalost dobivenom socijalno-stručnom pomoći i manje procijenjeno zadovoljstvo dobivenom socijalno-stručnom pomoći povezano s većim nepovjerenjem prema stručnjacima. Pri tome se, što su djeca starija, kod roditelja uočava manje spremnosti za traženje socijalno-stručne pomoći i više nepovjerenja u traženju socijalno-stručne pomoći. Pitanje povjerenja pri traženju socijalno-stručne pomoći istraživao je Vohs (1998, prema Lee, 2015) te se pokazalo da razina socijalnostručne pomoći nije bila na razini koju su očekivali roditelji. Isto tako, rezultati su pokazali da roditeljima nedostaje više senzibiliteta stručnjaka te potreba za većom emocionalnom i psihološkom podrškom.

Istovremeno je nelagoda za traženje socijalno-stručne pomoći izvjesnija ako obitelj živi u Vinkovcima nego u Rijeci te, neovisno o tome, ako živi na selu, a ne u gradu. Siromaštvo je dublje i teže na istoku Hrvatske, kao i u seoskim sredinama (Nestić i Vecchi, 2007), pa je upitno koliko je u takvim sredinama nositeljima lokalne vlasti prioritetan zadatak ulaganje u zapošljavanje i organiziranje timova stručne pomoći za obitelji djece $s$ teškoćama u razvoju. U razumijevanju rezultata vezanog uz veću nelagodu roditelja koji žive na selu može se pretpostaviti da je takva pomoć vrlo rijetka i neuobičajena i na nju roditelji nisu navikli, budući da je prema Šućur i sur. (2016) sustav socijalne zaštite u Hrvatskoj poprilično centraliziran jer se na regionalnoj i lokalnoj razini izdvaja svega 0, $43 \%$ BDP-a ili tek oko $2 \%$ od ukupnih izdvajanja za socijalnu zaštitu, dok se sa središnje razine u 2013. godini izdvajalo 98 \% od ukupnih sredstava za programe socijalne zaštite. U Republici Hrvatskoj sustav podrške roditeljima s djecom s teškoćama u razvoju (rana intervencija), usluge rane intervencije još su uvijek centralizirane prema glavnom gradu. Matijaš (2012) navodi kako je iz razgovara sa stručnjacima vidljivo da su obitelji nerijetko prisiljene promijeniti mjesto stanovanja kako bi svome djetetu osigurali što kvalitetniji rast i razvoj. Osim centralizacije, kao velik problem u Hrvatskoj navodi se segmentacija brige o biopsihosocijalnom zdravlju djeteta: zdravstveni sustav brine o medicinskom zdravlju, sustav socijalne skrbi brine o socijalnom području, institucije odgoja i obrazovanja brinu o edukacijskom zdravlju. Manjkava suradnja među tim sustavima dodatno otežava roditeljima i djeci traženje pomoći.

Podatak da s dobi djeteta roditelji razvijaju više nepovjerenja prema stručnjacima posebno je zabrinjavajući. Teško je reći što je tome razlog. Pećnik i Pribela-Hodap (2013) navode kako je moguće, s obzirom na tempo napredovanja društva, a prethodne generacije stručnjaka nisu upoznate $s$ novim zahtjevima koji se pred pojedine roditelje stavljaju, stoga nisu često u stanju pružiti dovoljno dobre odgovore roditeljima koji se susreću s nizom pitanja i izazova vezanih za odgoj i obrazovanje svoje djece. Sva dosadašnja istraživanja naglašavaju manjkavu ili izrazito nedostupnu 
formalnu stručnu podršku posebno u ruralnim sredinama te činjenicu da se, što je dijete starije, sužavaju oblici podrške i potpore u lokalnoj zajednici za obitelj i dijete. Opravdano je, s bioetičkog stajališta, postaviti pitanja o kvaliteti odnosa stručnjaka prema obiteljima i djeci u smislu uvažavanja njihovih prava u odlučivanju tijekom planiranja stručne pomoći kao i tijekom evaluacije iste i samim time učvršćivanja povjerenja kao garancije za buduću suradnju. Koliko su u realizaciji opće svrhe dobrobiti djeteta s teškoćama u razvoju (Konvencija o pravima djeteta, 1989) važne vrijednosti i norme postavljene na široj multidisciplinarnoj platformi različitih disciplina (medicina, filozofija, sociologija, bioetika i druge) pokazuju analize koje daje Murano (2019) koja ističe da je u pružanju profesionalne pomoći o kojoj je riječ u ovom radu potrebno, osim stručnih pristupa, dati prostora i etičkim analizama radi preispitivanja osjetljivosti stručnjaka na etička pitanja u radu sa svojim korisnicima. Iako rezultati istraživanja pokazuju da nema razlika u učestalosti traženja i zadovoljstvu dobivenom stručnom podrškom s obzirom na mjesto stanovanja, pokazalo se kako su značajnoj vezi niža procijenjena učestalost dobivene stručne pomoći i procijenjeno zadovoljstvo dobivenom stručnom podrškom $s$ većim nepovjerenjem u traženju stručne pomoći. Drugim riječima, može se implicirati da će se, ako se omogući iskustvo dobivanja socijalno-stručne podrške (dostupnost usluga svim obiteljima), utjecati i na manju nelagodu pri traženju iste, što će posljedično dovesti do učestalijeg primanja stručne podrške za dijete. Navedeno dopunjuje i iznenađujući podatak da je čak pet roditelja u ovom istraživanju navelo da dijete nije uključeno niti u jedan oblik stručne pomoći (poglavlje sudionici istraživanja) bez obliza što su bili uključeni u neki organizirani oblik podrške bilo kroz udrugu, bilo kroz instituciju. Istraživanja kontinuirano pokazuju da je dostupnost resursa u zajednici povezana $s$ češćim traženjem stručne podrške (Redmond, Spoth i Trudeau, 2002, National Academies of Sciences, Engineering, and Medicine, 2016).

Zemlje poput Velike Britanije i Cipra tome problemu doskočile su kroz uvođenje koordinatora koji, u suradnji s obitelji, koordinira pružanje usluga (Soriano, 2005). $\mathrm{Na}$ taj način roditelji su od najranije djetetove dobi povezani s koordinatorom koji ih vodi kroz cjelokupan proces rane intervencije (Ajduković, 2008). U Republici Hrvatskoj cjelokupni program rane intervencije je, nažalost, još uvijek u začetku. Obiteljski centri, Centri za socijalnu skrb, udruge civilnog društva, vjerske organizacije te centri predškolskog odgoja provode različite programe ranih intervencija s djecom i njihovim roditeljima. Naravno, osim navedenih mjesta mogu postojati i druga mjesta u pružanju formalne socijalno-stručne pomoći. Neke od intervencija/programa još uvijek nisu u dovoljnoj mjeri zastupljene, ali se radi na njihovom razvijanju. Kao dobar primjer strateškog dokumenta svakako valja izdvojiti Nacionalni plan aktivnosti za dobrobit, prava i interese djece 2006. - 2012., koji je 
prepoznao važnost unapređenja roditeljskih kompetencija koje je Ajduković (2008) istaknula kao bitne u ovom procesu.

Uz zagovaranje postavljanja sveobuhvatnog, integriranog i dostupnog sustava podrške roditeljima djece s teškoća u razvoju, odnosno svim roditeljima, potrebno je paralelno raditi na uvjerenjima društva o roditeljstvu, kao uvjerenjima samih roditelja. Naime, čini se da bi se trebali poduzeti napori da se u društvu „normalizira“ činjenica da gotovo svi roditelji - neki rjeđe, neki češće - trebaju stručnu podršku. U prilog tome idu podaci istraživanja koji pokazuju, iako se 85 \% roditelja slaže s tim da je traženje stručne pomoći znak roditeljske odgovornosti, da je kod dva od pet roditelja prisutno uvjerenje da pomoć trebaju samo problematične obitelji, a kod jednog od osam da su djeca nakon roditeljeva traženja pomoći "obilježena" (Pećnik i Pribela-Hodap, 2013). I na kraju, važno je kontinuirano ulagati u odnosne kompetencije stručnjaka u području rane intervencije - stvaranje partnerstva s roditeljima i stvaranje odnosa povjerenja, poštovanja, otvorene komunikacije i jednakosti.

Vezano uz slabosti ovog istraživanja, nisu svi roditelji djece s teškoćama u razvoju bili uključeni, a jedan dio njih nije vratio ispunjene upitnike. $U$ budućim bi istraživanjima trebalo ići u ispitivanje s većim uzorkom (pokušati obuhvatiti i druge regije $\mathrm{u} R \mathrm{RH}$ ) te uključiti i druge parametre, npr. spol roditelja, informiranost o izvornima podrške u lokalnoj zajednici, razinu obrazovanja, partnerski status, prva iskustva kod traženja podrške, spremnost na traženje podrške u drugim životnim područjima, članstvo u udruzi za djecu s teškoćama ili ne, zanimanje roditelja, razna stresa, doživljaj roditeljske kompetentnosti i roditeljskog stresa, vrsta stručne pomoći, u odnosu na koju razinu podrške se koja vrsta stručne pomoći dobiva, te neka obilježja samih stručnjaka koji osiguravaju formalnu pomoć ranjivim skupinama, osobito osobine koje se odnose na ispunjavanje bioetičkih zahtjeva poput uvažavanja mišljenja roditelja u planiranju stručnih postupaka i davanja informiranog pristanka za uključivanje u određene postupke. Isto tako, bilo bi dobro provesti kvalitativno istraživanje - fokus grupe ili intervjue s roditeljima. $S$ obzirom na temu i specifična iskustva, upravo tim kanalom moguće je dobiti snažnija iskustva iz kuta roditelja starije djece.

Zaključno, može se reći da se u skupu promatranih varijabli uočavaju ključni rezultati u oblikovanju smjernica za unapređivanje sustava pružanja formalne stručne pomoći u centrima za socijalnu skrb, vrtićima i školama za roditelje djece $s$ teškoćama u razvoju:

1. veće nepovjerenje prema traženju stručne pomoći može se povezati s većom dobi djeteta kao i procijenjenom nižom učestalosti dobivene socijalno-stručne podrške; 
2. veća spremnost u traženju socijalno-stručne pomoći može se povezati s nižom dobi djeteta;

3. roditelji iskazuju teorijski gledano previsoku nelagodu u traženju socijalnostručne pomoći, što je relativno problematičan rezultat s obzirom na to da se radi o roditeljima djece kojima je u većini slučajeva neophodna stručna pomoć. Veća nelagoda u traženju socijalno-stručne pomoći može se povezati s činjenicom da roditelji žive u Vinkovcima (a ne u Rijeci), odnosno na selu (a ne u gradu);

4. niža učestalost i zadovoljstvo dobivenom stručnom podrškom povezana je s većim nepovjerenjem u traženju stručne pomoći.

Ove rezultate treba promatrati kao preliminarne nalaze koje bi bilo zanimljivo provjeriti s reprezentativnim uzorkom za Hrvatsku te nove pokazatelje dovesti u relaciju s nekim drugim parametrima kao što je navedeno. Ipak, iz navedenih iskaza roditelja djece s teškoćama u razvoju je evidentno da bi socijalno-stručna pomoć prema njima i njihovim obiteljima mogla i trebala biti kvalitetnija. U tom smislu autorice se nadaju da će se istraživanja nastaviti kako bi se (uz kontaktiranje autorica rada) eventualno ovo istraživanje proširilo i/ili produbilo u odgovorima na nova istraživačka pitanja i propitivanja optimalnih modela prevladavanja uočenih prepreka u traženju stručne pomoći roditelja djece s teškoćama u razvoju. Značaj dobivenih rezultata ogleda se u doprinosu unaprjeđivanja kvalitete socijalno-stručne podrške i pomoći obiteljima djece s teškoćama u razvoju jer ukazuje da je roditeljska procjena učestalosti i kvaliteta dobivene stručne pomoći povezana s njihovom spremnosti da se kontinuirano obraćaju službama pružanja socijalnih, psiholoških, edukacijsko-rehabilitacijskih i/ili edukacijskih usluga.

\section{LITERATURA}

1. Ajduković, M. (2008). Rane intervencije i ostale intervencije u zajednici kao podrška roditeljima pod rizicima. U: Pravo djeteta na život u obitelji. Zagreb: Ured UNICEF-a za Hrvatsku.

2. Akister, J. \& Johnson, K. (2004). The Parenting Task: Parents'concerns and where they would seek help. Journal of Family Social Work, 8 (2), 53-64.

3. Attree, P. (2005). Parenting support in the context of poverty: a menta-synthessis of the qualitative evidence. U: Health and Care in the Community, 13 (4), 330-337.

4. Batista, N., Jug, L. \& Milić Babić, M. (2014). Uloga organizacija civilnog društva u podršci obitelji djece $s$ teškoćama u razvoju. U: Zbornik sažetaka, 6. konferencija socijalnih radnika: Socijalni rad u vrijeme socijalne i ekonomske krize / Štefica Karačić (ur.). Zagreb: Hrvatska udruga socijalnih radnika, 49-49.

5. Blaži, A. \& Kolarić, B. (2015). Iskustva i zadovoljstvo roditelja djece s orofacijalnim rascjepom pruženom skrbi u Republici Hrvatskoj. Logopedija, 5 (2), 18-24.

6. Batinić M. \& Denona, I. (2000). Djeca s cerebralnom paralizom u dječjem vrtiću „Krnjevo“. U: Kvaliteta življenja osoba s cerebralnom paralizom. Zagreb: Hrvatski savez udruga cerebralne i dječje paralize. 
7. Breitkreuz, R., Wunderli, L., Savage, A. \& McConell, D. (2014). Rethinking resilience in families of children with disabilities: a socioecological approach. Community, Work \& Family, 17 (3), 346-365.

8. Collins, W. A., Maccoby, E., Steinberg, L., Hetherington, E. M. \& Bornstei, M. (2000). Contemporary research on parenting: the case for natureand nurture. American Psychologist, 55, 218-232.

9. Convention of the Rights of the Child. Adopted and opened for signature, ratifi cation and accession by General Assembly resolution 44/25 of 20 November 1989. https://www.ohchr.org/en/ professionalinterest/pages/crc.aspx (pribavljeno 9. 5. 2019.)

10. Diminić-Lisica, I. \& Rončević-Gržeta, I. (2010). Obitelj i kronična bolest. Medicina Fluminensis, 46 (3), 300-308.

11. Denona, I. \& Batinić, M. (2002). Problemi prihvaćanja i prilagodbe roditelja na dijete s cerebralnom paralizom. U: Znanjem do izjednačavanja mogućnosti za osobe s invaliditetom.

12. Dobrotić, I. \& Pećnik, N. (2013). Doživljaj roditeljstva, roditeljsko ponašanje i prakse: postoje li rodne razlike? U: Kako roditelji i zajednice brinu o djeci najmlade dobi u Hrvatskoj. Zagreb: Ured UNICEF-a za Hrvatsku.

13. Fareo, D. O. (2015). Counselling Intervention and Support Programmes for Families of Children with Special Educational Needs. Journal of Education and Practice, 6 (19), 103-109.

14. Ferić, M. (2015): Razvoj sveobuhvatnog sustava podrške obiteljima: Prilike i izazovi (u) Kaljača, S., Nikolić, M. (ur.) Unaprjeđenje kvalitete života djece i mladih. Tematski zbornik I, Tuzla, 84-94.

15. Fox, L. \& Swett, J. (2017). Implementing partnerships with families to promote the social and emotional competence of young children. In: Aligning and Integrating Family Engagement in Positive Behavioral Interventions and Supports. (63-72) Eds: West, M. D., Garbacz, S. A., Lane, K. L. Kincaid D. US:PBIS,

16. Ghate, D. \& Hazel, N. (2004). Parenting in Poor Environments: Stress, support and coping: Summary of key messages for policy and practice from a major national study.

17. Girio-Herrera, E., Owens J. S. \& Langberg J. M. (2013). Perceived barriers to help-seeking among parents of at-risk kindergarteners in rural communities. Journal of Clinical Child Adolescent Psychology, $42(1), 68-77$.

18. Godoy, L., Mian, N. D., Eisenhower, A. S. \& Carter, A. S. (2014). Pathways to Service Receipt: Modeling Parent Help-Seeking for Childhood Mental Health Problems. Administration and Policy in Mental Health and Mental Health Services Research, 41 (4), 469-479.

19. Ilišin, V. \& Radin, F. (2016). Mladi uoči trećeg milenija. Zagreb: Institut za društvena istraživanja ; Državni zavod za zaštitu obitelji, materinstva i mladeži.

20. Ivšac Pavliša, J. (2010). Atipični komunikacijski razvoj i socioadaptivno funkcioniranje u ranoj dobi. Društvena istraživanja, 19 (1-2), 279-303.

21. Košiček, T., Kobetić, D., Stančić, Z. \& Joković Oreb, I. (2009). Istraživanje nekih aspekata rane intervencije u djetinjstvu. Hrvatska revija za rehabilitacijska istraživanja, 45 (1), 1-14.

22. Kranželić, V., Kovčo Vukadin, I. \& Ferić, M. (2016). Etička pitanja u istraživanjima s obiteljima: primjer smjernica. Kriminologija i socijalna integracija, 24 (1) 179-210.

23. Lee, Y.H. (2015): The meaning of early intervention: A parent's experience and reflection on interactions with professionals using a phenomenological ethnographic approach. International Journal of Quallitative Studies and Health Well-being, 10. https:/www.ncbi.nlm.nih.gov/pmc/articles/ PMC4511832/pdf/QHW-10-25891.pdf, pristupljeno 17. 11. 2018.

24. Leutar, Z. \& Štambuk, A. (2007). Invaliditet u obitelji i izvori podrške. Hrvatska revija za rehabilitacijska istraživanja, 43 (1), 47-61.

25. Leutar, Z. \& Oršulić, V. (2015). Povezanost socijalne podrške i nekih aspekata roditeljstva u obiteljima djece s teškoćama u razvoju. Revija za socijalnu politiku, 22 (2), 153-176.

26. Lyons, B. (2011). Obliging children. Medical law review, 19(1), 55-85. 
27. National Academies of Sciences, Engineering, and Medicine (2016). Parenting Matters: Supporting Parents of Children Ages 0-8. Washington, DC: The National Academies Press. https://doi. org/10.17226/21868., pristupljeno 17. 11. 2018.

28. Nestić, D. \& Vecchi, G. (2007). Regional Poverty in Croatia. U: Social Policy and Regional Development Proceedings, Ur. Lovrinčević, Ž., Mervar, A. Nestić, D., Starc, N., Stubbs, P.,; Sumpor, M. \& Švaljek, S., Zagreb, Ekonomski institut, Zagreb i Friedrich Ebert Stiftung, 65-90.

29. Martinac Dorčić, T. (2008). Razlike između majki i očeva djece s cerebralnom paralizom u rizičnim i zaštitnim faktorima te prilagodbi. Hrvatska revija za rehabilitacijska istraživanja, 44 (2), 63-78.

30. Martinac Dorčić, T. \& Ljubešić, M. (2008). Psihološka prilagodba roditelja na dijete s kroničnom bolesti. Društvena istraživanja, 18 (6), 1107-1129.

31. Matijaš, T. (2012). Uloga zdravstvenog sustava u domeni rane intervencije u djetinjstvu. Specijalistički rad. Zagreb: Edukacijsko-rehabilitacijski fakultet.

32. Matijaš, T., Ivšac Pavliša, J. \& Ljubešić, M. (2014). Sustav zdravlja u području rane intervencije u djetinjstvu. Paediatria Croatica, 58 (4), 303-309.

33. Milić Babić, M. (2012) Neke odrednice doživljaja roditeljske kompetentnosti u obiteljima djece $s$ teškoćama u razvoju. Napredak, 154 (1-2), 83-102.

34. Milić Babić, M., Franc, I. \& Leutar, Z. (2013). Iskustva s ranom intervencijom roditelja djece $s$ teškoćama u razvoju. Ljetopis socijalnog rada, 20 (3), 453-480.

35. Morrison, W.\& Feudtner, C. (2009). The contested territory of medical decision-making for children. In Penn Center guide to bioethics (p. 449). Springer, New York.

36. Murphy, T. F. (2018). Bioethics, children, and the environment. Bioethics, 32(1), 3-9.

37. Oh, E.\& BayerJ. K. (2015) Parents' help-seeking processes for early childhood mental health problems. Child and Adolescent Mental Health, 20 (3) 149-154.

38. Pećnik, N. \& Starc, B. (2010). Roditeljstvo u najboljem interesu djeteta i podrška roditeljima najmlađe djece (Rastimo zajedno) Zagreb: UNICEF.

39. Pećnik, N. \& Pribela Hodap, S. (2013). Podrška roditeljstvu u razdoblju ranog razvoja djeteta. U: Kako roditelji i zajednice brinu o djeci najmlade dobi u Hrvatskoj. Zagreb: Ured UNICEF-a za Hrvatsku

40. Pećnik, N. (2013). Kako roditelji i zajednice brinu o djeci najmlade dobi u Hrvatskoj. Zagreb: Ured UNICEF-a za Hrvatsku.

41. Pećnik, N. (2014). Suvremeno roditeljstvo i njegova društvena podrška. U: Roditeljstvo u najboljem interesu djeteta i podrška roditeljima najmlade djece s teškoćama u razvoju. Zagreb: Ured UNICEF-a za Hrvatsku.

42. Pelčić, G. \& Gjuran Coha, A. (2010). UNESCO, bioetika i dijete. JAHR, 1(1), 63-68.

43. Radman-Funarić, M. (2014). Regionalna neravnoteža u Republici Hrvatskoj - Z test. U: Konkurentnost, ekonomski rast i blagostanje / Cini, Vladimir; Borozan, Đula; Ferenčak, Ivan (ur.). Osijek, Sveučilište J. J. Strossmayera u Osijeku, Ekonomski fakultet u Osijeku.

44. Raguž, A. (2016). Socijalna podrška i uvjerenja o traženju stručne pomoći kod roditelja djece s teškoćama u razvoju. Diplomski rad Filozofskog fakulteta Sveučilišta u Rijeci.

45. Redmond, C., Spoth, R. \& Trudeau, L. (2002): Family and Community Level Predictors of Parent Support Seeking. Journal of Community Psychology, 30, 153-171.

46. Roehlkepartain, E. C., Scales, P. C., Roehlkepartain, J. L. \& Rude, S. P. (2002). Building Strong Families: An In-depth Report on a Preliminary Survey of What Parents Need to Succeed. Search Institute, YMCA and Minneapolis, Chicago.

47. Sarason, I. G., Levine, H. M. \& Basham, R. B. (1983). Assessing social support: The Social Support Questionnaire. Journal of Personality and Social Psychology, 44, 127-139.

48. Schembri Lia, E. \& Abela, A. (2016). Not Broken but Strengthened: Stories of Resilience by Persons with Acquired Physical Disability and Their Families. Australian and New Zealand Journal of Family Therapy. 37, 400-417 doi: 10.1002/anzf.1156. 
49. Soriano, V. (ur) (2005). Early Childhood Intervention Analysis of Situations in Europe. Key Aspects and Recommendations. Dostupno na: https://www.european-agency.org/agency-projects/early-childhoodintervention/early-childhood-intervention-2003-2004, pristupljeno 15. ožujka 2016.

50. Spoth, R. \& Conroy, S. (1993). Survey of Prevention-Relevant Beliefs and Efforts to Enhance Parenting Skills among Rural Parents. The Journal of Rural Health, 9, 277-239.

51. Šućur, Z., Babić, Z., Urban, I. \& Baran, J. (2016). Struktura naknada, izdaci i korisnici programa socijalne zaštite u Republici Hrvatskoj. Zagreb: Ministarstvo socijalne politike i mladih.

52. Zakon o socijalnoj skrbi. Narodne novine, broj 157/13 , 152/14, 99/15. https://narodne-novine.nn.hr/ clanci/sluzbeni/2012_03_33_798.html

53. Wallander, J. L. \& Varni, J. W. (1998.). Effects of Pediatric Chronic Physical Disorders on Child and Family adjustment. Journal of Child Psychology and Psychiatry, 39(1), 29-46. 


\section{Distrustfulness, Readiness and} Discomfort of Parents of Children with Developmental Difficulties While Seeking Social and Professional Support

\section{SUMMARY}

The main goal of this study was to examine to what extent are parents of children with developmental difficulties ready to seek social and professional support. The first specific aim of research was to determine the ways in which the beliefs (distrustfulness, readiness and discomfort in seeking of social and professional help) of parents of children with developmental difficulties in future seeking social and professional help are related to the parents' estimated frequency of previously obtained social and professional support and parents' estimated frequency of satisfaction with previously social and professional support, along with some socio-demographic characteristics (a place of the residence and child's age). The beliefs of parents of children with developmental difficulties in seeking professional support, parents' estimated frequency of obtained professional support, and parents' estimated frequency of satisfaction with professional support are provided by 102 parents of children with developmental difficulties living in rural and urban areas of Rijeka and Vinkovci towns. A total of $73(71.6 \%)$ mothers $($ Mage $=40.14)$ and $29(28.4 \%)$ fathers (Mage $=41.52)$ of children up to 15 years of age participated in the study.

The estimated frequency of social and professional support obtained and the estimated frequency of satisfaction with previously social and professional support are negatively associated with greater distrustfulness in seeking social and professional support. As children were older, parents were less ready to seek professional support and more distrustful while seeking professional assistance. By comparing the parents in Vinkovci and Rijeka, as well as by comparing the parents living in the city, and the parents who live in the village, it was found that parents living in Vinkovci as well as parents living in the village show a major discomfort in seeking social and professional support. The authors hope that the results can help in future researches and in improving the systematic provision of professional help and support to families of children with developmental difficulties. They believe that this work is important in improving the quality of social and professional support and helping families of children with developmental difficulties because it points to a theoretically interpreted low parental assessment of the frequency and quality of the received professional support.

Keywords: children with developmental difficulties, support for parents, village, expert help, regional differences. 